\title{
Policy pivot in Puget Sound: Lessons learned from marine protected areas and tribally-led estuarine restoration
}

Patrick Christie $^{a, *}$, David Fluharty $^{\mathrm{b}}$, Haley Kennard ${ }^{\mathrm{c}}$, Richard Pollnac ${ }^{\mathrm{d}}$, Brad Warren $^{\mathrm{e}}$, Terry Williams ${ }^{f}$

a School of Marine and Environmental Affairs and Henry M. Jackson School of International Studies, University of Washington, Box 355685, Seattle, WA 98105, USA

${ }^{b}$ School of Marine and Environmental Affairs, University of Washington, Box 355685, Seattle, WA 98105, USA

' Marc Hershman Marine Policy Fellow at the Makah Tribe, WA Sea Grant, 3716 Brooklyn Ave NE, Seattle, WA 98105, USA

d Department of Marine Affairs, University of Rhode Island, Coastal Institute, 1 Greenhouse Road, Suite 205, Kingston, RI 02881-2020, USA

e National Fisheries Conservation Center, PO Box 39615, Seattle, WA 98103, USA

${ }^{f}$ Commissioner of Treaty Rights, Natural Resources Department, Tulalip Tribes, 6406 Marine Dr., Tulalip, WA 98271, USA

*Corresponding author. E-mail addresses: patrickc@uw.edu (P. Christie), fluharty@uw.edu (D. Fluharty), hkennard17@gmail.com (H. Kennard), pollnacrb@gmail.com (R.Pollnac),brad@globaloceanhealth.org (B.Warren), terrywilliams@tulaliptribes-nsn.gov (T. Williams).

This is the accepted manuscript of a paper published in Ocean and Coastal Management. The final version may be found at https://doi.org/10.1016/j.ocecoaman.2018.05.020.

\section{Abstract}

Environmental change amplifies the challenge of protecting and restoring Puget Sound. As rising pressures from population growth, development, unsustainable resource use, climate impacts and other factors alter this urbanizing basin, efforts to recover salmon and ecosystem health and to enhance climate resilience face unprecedented social complexities and intensifying competition for space. A multi-method study of citizen and practitioner perspectives on protection and restoration suggests that capacity to manage under these conditions can be improved through strengthening an approach that has already become central in restoration practice: multiple-benefit planning. In this research, we examine and compare planning approaches used to develop marine protected areas (MPA) and estuary restoration (ER) projects in Puget Sound. Surveying non-tribal public attitudes toward these projects, we found limited knowledge concerning existing MPAs but support for wider use of such protections. We find that initiatives pursuing conservation, protection, restoration and 
resilience can gain advantage from (a) broadly inclusive and collaborative planning; (b) recognition of tribal treaty rights, management authorities, and leadership; (c) careful consideration and mitigation of project impacts on affected people (e.g. especially tribal and non-tribal fisheries for MPAs; farm interests and landowners for restoration projects). We note that "no-take" MPA designation has stalled, while ER efforts are overcoming sharp objections and controversies by crafting projects to deliver multiple social-ecological benefits: improved flood control and drainage, salmon recovery, recreational enjoyment, and resilience to climate change. Comparable strategies have not yet evolved in designation of "no-take" MPAs in Puget Sound. We offer conclusions and recommendations for accelerating conservation and resilience initiatives to keep pace with a changing environment. A key human dimensions research-based recommendation is that increasing environmental pressures intensify the need to strengthen collaborative and sustained planning and implementation processes.

\section{Introduction}

We examine two approaches to restore the Puget Sound basin in light of multiple drivers of change that place an accelerating squeeze on marine and coastal habitats and limit their ability to provide ecosystem services. These drivers constrain recovery measures where tidal wetlands have been lost to development (Cereghino, 2015). Marine Protected Area (MPA) designation and estuarine restoration (ER) represent two leading approaches among others to manage Puget Sound sustainably. MPAs are an important marine spatial planning tool defined as "a clearly defined geographical space, recognized, dedicated and managed, through legal or other effective means, to achieve the long-term conservation of nature with associated ecosystem services and cultural values." (Dudley, 2008:8). ER is defined to include mitigation, management of nearshore processes and large-scale projects such as flood control, breaching dikes and reopening tidal areas and other measures to adapt to climate change (Elliott et al., 2007). Each approach is seen by tribal, state, federal managers and non-governmental stakeholders as having benefits and costs within a coupled social-ecological system to achieve resilience. Understanding of the conditions and processes leading to successful MPA and ER implementation is the goal of the research being reported. The perspectives of MPA and ER leaders, participants, and the public were elicited using a multi-methods approach. It is clear that "saving Puget Sound" is an on-going process and one that requires constant adaptation (Lombard, 2006).

In this paper, we first provide the context for evolving efforts to manage Puget Sound. Second, research multi methods are described. Third, case studies of MPA and ER are presented. Finally, we conclude and make recommendations on options to counter the accelerating consequences of population growth, development, unsustainable resource use, climate impacts and other factors in Puget Sound.

\section{Historical context and background}

Puget Sound is a large (2642 km², 1020 square mile) fjord-type ecosystem (Burns, 1990), the third largest estuary in the continental United States (Fig. 1). It is part of the larger Salish Sea, that extends into Canada. Puget Sound is home to critically endangered orcas, salmon and 
habitats and the source of commercial, recreational and cultural resources for millions of people from diverse backgrounds (PSP, 2016). There are approximately $4023 \mathrm{~km}$ (2500 miles) of shoreline (Gelfenbaum et al., 2006). Its 16 large river estuaries have been heavily modified with an estimated $74 \%$ ( 26,062 ha, 64,400 acres) of critically important wetlands lost (Gelfenbaum et al., 2006; Simenstad et al., 2011). Population growth throughout the region shows an anticipated rise from over 4,000,000 to 5,500,000 persons in the next few decades. This is expected to result in suburban sprawl and increases the impervious surface throughout the region, adding pressure on existing uses (Gelfenbaum et al., 2006). On top of those pressures, climate impacts (rising sea levels, loss of snowpack, seasonal compression of river flows, increasing storm intensity and storm surge), contribute to coastal erosion, flooding and sedimentation, limiting options for restoration and conservation.

Fig. 1. Puget sound.

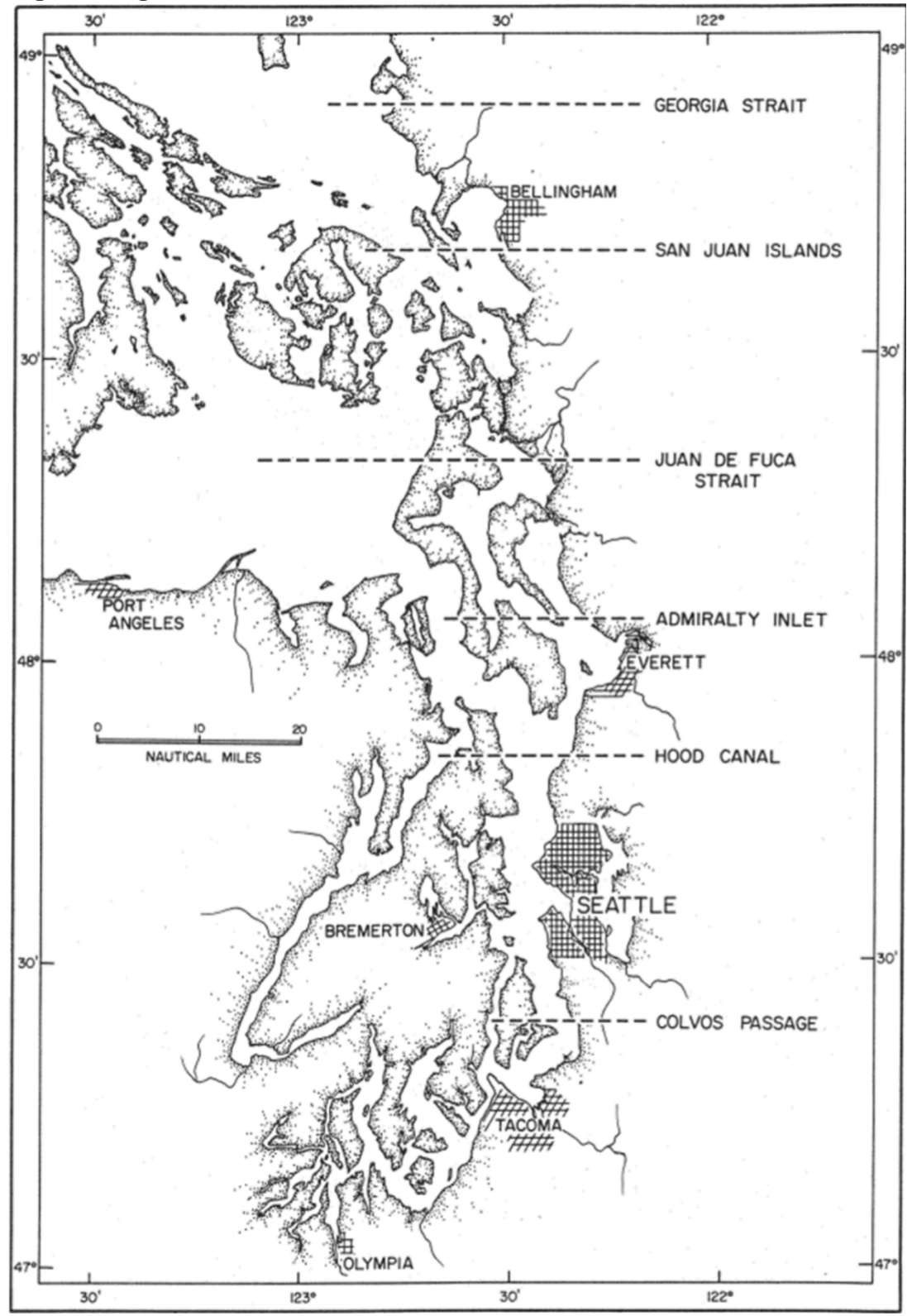


Current management of Puget Sound reflects the evolution of issues over a period of only a few hundred years. Native peoples were accustomed to the abundant shellfish, salmon and cedar culture afforded by the basin (Williams and Hardison, 2012). With the arrival of AngloEuropeans, treaties and new management authorities restricted native peoples' access to resources and allowed rapid expansion of extractive economic activities (Chasan, 1981; Montgomery, 2003). Successive development of ports for West Coast and Asian commerce, arrival of intercontinental railroads, development of national and international markets for lumber, fish, and other products exacted a toll on the important estuaries of Puget Sound. Development accelerated with the discovery of gold in Alaska, wartime economies of two world wars and especially with the rise of the commercial aviation era. In the second half of the 20th Century, new concerns began to arise due to marine pollution, overuse of coastal resources and increasing demands on the Puget Sound ecosystem from increased population growth (Bish et al., 1975). As residential and industrial uses crowded the shores and estuaries, bulkheads and other shoreline defenses proliferated (Ruckelshaus et al., 2009), squeezing coastal environments between human society and the region's changing, rising waters.

Starting in the late 1960 s and early 1970 s citizens began voicing concerns about changes in the marine environment and began pushing for environmental protections for Puget Sound (Bish et al., 1975). New federal laws called upon States to protect shorelines, water quality, fisheries and marine mammals and ecological functions in order maintain resources and the environment (Bish, 1982). This constituted a considerable shift in priorities for management of Puget Sound. One highlight of these shifts at the State level included the formation of the Puget Sound Water Quality Authority to assist in a new emphasis on coordination among tribes, the state and federal agencies as well as stakeholders for Puget Sound recovery. This drive for coordinated response to Puget Sound environmental problems led to development of the Northwest Straits Commission to link local conservation issues with County level authorities (Murray and Metcalf, 1998). However, the problems were larger than could be solved at a local level.

Ambitious and innovative planning processes like the Puget Sound Partnership (Puget Sound Partnership, 2016; http://www.psp.wa.gov/) combine the interests in protecting and restoring Puget Sound with interests in recovering salmon populations, seeking to improve the Puget Sound marine environment and prevent continued deterioration. The Boldt Decision (United States v. Washington, 384 F. Supp. 312, 1974) reaffirmed tribal treaty rights to fish in Washington State. Washington State Fish and Game officers in the 1960s and 70s were forcing tribal fishermen from their treaty reserved fishing areas. Judge Boldt of the United States District Court for the Western District of Washington found that tribes have a reserved right to fish, are entitled to $50 \%$ of the available harvest, and are co-managers of the fish stocks with the State of Washington. This decision was affirmed by the United States Court of Appeals for the Ninth Circuit. Since that decision, federally-recognized tribes have increasingly asserted their fishing rights and responsibilities for Puget Sound recovery (Singleton, 2009). As comanagers of salmon and shellfish resources, each federally recognized tribe has the right to $50 \%$ of harvests in Usual and Accustomed fishing areas. Tribes continue to assert their rights through court cases and organizations such as the Northwest Indian Fisheries Commission 
(https://nwifc.org/). Tribal rights, responsibilities, and policies are a major influence on planning and implementation of MPAs and ERs in Puget Sound. This analysis explores the how these diverse authorities and tools are used in efforts to reverse deterioration and increase resilience, and how their implementation is shaped by the interests and rights of various social groups.

\section{Research approach and methods}

The initial aim of this research was to understand constraints on and opportunities for the development of MPAs and to assess whether and how stalled MPA planning processes might be revived and improved. Research later widened in scope based on initial findings to consider ERs, an approach to protecting and recovering coastal habitats that continues to gain ground in Puget Sound. Analyzing one largely stalled planning process (MPA) and one dynamic planning process (ER) in the same context helps identify key similarities and distinctions in design and implementation processes, leading to process recommendations for both approaches. The methods employed also evolved over the course of this research project-from social surveys to qualitative, semi-structured interviews -in response to cultural appropriateness considerations and given the exploratory nature of the latter research.

\subsection{MPA research: approach and methods}

Formal social survey techniques on MPAs built upon prior research (Hard et al., 2012; Hoelting et al., 2013) and were conducted to answer the following general questions. (1) What are the conditions and processes that lead to successful MPA implementation in diverse contexts? (2) What are the opportunities for the Puget Sound Partnership and other Puget Sound MPA planning processes to improve MPA management effectiveness? And (3) Should and can MPAs be used to increase social and ecological resilience in response to rockfish recovery needs, habitat loss, changing use patterns of Puget Sound resources, ocean acidification, and concomitant climate stresses? Survey questions analyzed for this paper can be found in the analysis section. In general, we used a combination of open-ended, dichotomous (yes/no), and Likert scale formats. Unfortunately, the sample for key informant interviews and the formal survey did not include tribal members because we were unable to secure tribal government approvals to conduct surveys. This is partially explained by the controversial nature of MPAs among tribal members-a finding that is explained in detailed and is related to their leadership in alternative methods for Puget Sound recovery, namely ERs.

Broadly structured social surveys were conducted in-person using Open Data Kit digital data collection software on Android-based cell phones. We used a modified partially random sampling approach (e.g., randomized time of day and selected every $\mathrm{N}^{\text {th }}$ person encountered, $\mathrm{N}$ depending on concentration of possible informant), and we used purposive sampling for key informants.

Structured social surveys were used to collect information near 12 MPA sites from 1) the general public and resource users and 2) key informants. Most questions had been used in prior studies involving authors (Hard et al., 2012; Hoelting et al., 2013). General public and resource users were questioned along the shoreline or at their homes within the vicinity of MPAs. This 
questionnaire consisted of 78 questions. A subgroup of this sample, resource users, were selfidentified as fishers or recreational SCUBA divers and questioned along the shoreline, boat launches, shoreline or other locations within the vicinity of a MPA or reference site. Key informants were people who were more engaged on issues pertaining to a given MPA (i.e., formation, implementation or management) and had significant historical knowledge about the areas. This questionnaire consisted of 51 questions. In addition to these detailed surveys, a short questionnaire focused on MPA awareness was used with people in grocery store parking lots near MPAs. Table 1 presents the sample size for the above three survey types in 12 MPA sites. The main MPA types presented in this analysis are those established by the Washington Department of Fish and Wildlife (WDFW) and the Washington Department of Natural Resources (WDNR). There are two types of WDFW MPAs (conservation areas and marine preserves), but the differences are not significant enough to warrant sub-dividing the sample for this analysis. Additional details on MPA types in Puget Sound are presented below.

Table 1. Number of surveys completed for 10 Washington Department of Fish and Wildlife (WDFW) and 2 Washington Department of Natural Resources (WDNR) MPA sites.

\begin{tabular}{|l|l|l|}
\hline Site Name & WDFW & WDNR \\
\hline Admiralty Head & 85 & 0 \\
\hline Bracketts Landing & 159 & 0 \\
\hline False Bay & 82 & 0 \\
\hline Friday Harbor & 96 & 0 \\
\hline Keystone & 108 & 0 \\
\hline Maury Island & 0 & 83 \\
\hline Orchard Rocks & 109 & 0 \\
\hline Salt Water State Park & 83 & 0 \\
\hline Smith \& Minor & 0 & 92 \\
\hline Sund Rock & 51 & 0 \\
\hline Titlow Beach & 92 & 0 \\
\hline Waketickeh Creek & 34 & 0 \\
\hline
\end{tabular}

\subsection{Restoration research: approach and methods}

Perspectives on estuary restoration in Puget Sound and a particular ER project, Qwuloolt ("marsh" in Lushootseed, the traditional language of the Tulalip and other regional tribes), were gathered through multiple methods: interviews, participant observation at a workshop, and personal communications were solicited from agency restoration practitioners, policy makers, tribal leaders, landowners, and other stakeholders. The research team conducted 13 semistructured key-informant interviews, not including preliminary interviews and fact-checking interviews; 12 of the 13 were individual interviews and one interview was of a group of three people. This qualitative approach was selected because it facilitates a deep exploration of local knowledge, perspectives, and experience while preserving the voices of interviewees (Tuler et al., 2002). This approach was also utilized because tribal informants and leaders advised researchers to avoid attempting surveys that can be perceived as too inflexible and extractive. Rather, they prefer a more conversational tone to the research in which tribal informants can influence the direction of the research event along with the research design (Smith, 2012). 
Interviewees were selected with input from the Treaty Rights Office of the Tulalip Tribes Natural Resources Department and agency restoration leaders to represent a variety of perspectives and roles in restoration in the Puget Sound. Interviewees included Tulalip Tribes staff as well as local state and federal agency representatives, and individuals involved in planning and coordination efforts to facilitate restoration activities.

The 13 semi-structured interviews were conducted between June and October 2016 and each interview lasted between 60 and $90 \mathrm{~min}$. The research team used an interview guide consisting of 17 questions, but allowed interviewees to shape the discussion and deviate from the planned questions based on their deep knowledge and expertise in the subject and practice of restoration. The interviews were transcribed and coded thematically using Atlas.ti software (http://atlasti.com/). 32 code categories were used, structured to highlight themes of governance, process, objectives, and institutional roles (Miles and Huberman, 1994; Saldaña, 2010). The coded data was further analyzed through the writing of theoretical memos, which were shared and discussed among members of the research team. Memoing is a widely accepted qualitative social science practice which allows the researcher to develop ideas and theoretically-rich explanations (Miles and Huberman, 1994), while adding credibility and traceability by creating a record of the researcher's analytical process (Saldaña, 2010; Given, 2008). Additional information was collected from peer-reviewed and "gray" literature published by tribes and agencies, from public records of state and county restoration planning processes, and from a workshop "Navigating Coastal Squeeze" (December 2016) which convened 80 agency leaders, practitioners and tribal leaders. The workshop served as a validation exercise (Corbin and Strauss, 2015) for the interview research in the greater context of exploring challenges and opportunities facing Puget Sound estuary restoration at a time of rapid urban growth and accelerating climate impacts. The workshop was organized jointly by this research team and Tulalip Tribes, with funding from Washington Sea Grant, Tulalip Tribes, and the US Bureau of Indian Affairs. Qualitative research findings are effectively presented when 'woven' into analysis of policies and theory (Tuler et al., 2002) and not reduced to phrases or descriptive statistics (Miles and Huberman, 1994). Rather the nuance and richness of the informant's perspective is retained through direct quotes.

\section{Results: MPAs case}

\subsection{MPAs in the Puget Sound context}

Washington has a long history of developing MPAs (Murray and Fergusson, 1998) of various definitions and with differing authorities: State Parks, Department of Natural Resources (WADNR), Washington Department of Fish and Wildlife (WDFW). There are 110 officially designated MPAs in Puget Sound (148,319 ha or 366,504 acres and almost $966 \mathrm{~km}$ or 600 miles of shoreline) of which 24 qualify for the national MPA system (Osterberg, 2012).

The main forms of Puget Sound MPAs are: no-fishing areas declared by the WDFW to improve fish populations and protect habitat (as "conservation areas" or "marine preserves"), diving/nofishing reserves spearheaded by SCUBA diving enthusiasts and sanctioned by WDFW (Sund Rock and Brackett's Landing), and aquatic reserves declared by WA Department of Natural Resources 
(WA DNR, http://www.dnr.wa.gov/managed-lands/aquatic-reserves) to regulate bottomland leasing in critical areas in order to improve marine habitat conditions. Coastal areas of various state parks also receive some degree of protection, but they are not part of the national MPA system.

In the 1990s and 2000s, there was considerable interest in the declaration of new MPAs in Puget Sound. The Northwest Straits Commission was established in 1998 after a failed National Marine Sanctuary designation process. Its county-level Marine Resource Committees were directed, in part, to promote local county-level marine protection by the designation of MPA networks (MurrayMetcalf, 1998). In 2008, the Washington State legislature required the Department of Ecology to convene a Marine Protected Areas Work Group to provide recommendations on how MPAs could be developed in Puget Sound and elsewhere (VanCleve et al., 2009). The Work Group report recommended that the legislature support establishment of a MPA network. The Puget Sound Partnership included measures in the biannual action agenda to explore the potential of MPAs:

"Marine Protected Areas (MPAs) are one management tool often used by federal, state, and local agencies to provide long term protection for marine resources. They can be effective tools when properly designed, effectively managed, and supported by marine resource users and managers ... By June 2014, PSP, in collaboration with WDFW and DNR will identify the threats, coverage gaps, and conservation concerns addressed by existing Puget Sound marine protected areas and assess the potential effectiveness of these MPAs to protect threatened species and habitats, including rockfish and forage fish." (Puget Sound Partnership, 2012:134).

In an attempt to protect declining rockfish populations, WDFW developed the Puget Sound Rockfish Conservation Plan (WDFW, 2011) in which the designation of more no-take MPAs was a priority policy. With the 2010 federal listing of three species of rockfish under the Endangered Species Act, MPAs were recommended to protect critical habitat. The draft recovery plan (NMFS, 2016:80) states:

"Therefore, in the areas we have assessed to have remaining high risk of bycatch despite the regulations put into place by WDFW in 2010 to limit bycatch (areas are the San Juan Basin and the eastern Strait of Juan de Fuca (generally east of Port Angeles) ..., we recommend beginning the scientific and public process to establish marine protected or rockfish conservation areas to protect listed rockfish."

There are seven WADNR Aquatic Reserves in Puget Sound. These MPAs are larger than the WDFW sites and are mainly focused on improved management of Washington State-owned bottom lands (through lease management) and do not limit fishing (which is outside the WADNR's mandate). Some impetus for MPAs in Washington may have come from the Marine Life Protection Act-led declaration of an ambitious MPA network in California (Kirlin et al., 2013) and support from the US federal government through the NOAA MPA Center (http://marineprotectedareas.noaa.gov/aboutmpas/mpacenter/). 


\subsection{Awareness and support for Puget Sound MPAs}

While enthusiasm for MPAs mounted nationally and internationally, MPAs in Puget Sound appear to have been inconsistently implemented or enforced. The design and implementation process has not consistently reached the standards described in Gunderson et al. (2008), including consistent monitoring and enforcement, engaging relevant stakeholder and communities in allocation decisions, and implementing educational programs. Hard et al. (2012) report on the social surveys of 156 MPA leaders and resource users and 936 citizens near nine MPA sites. They found that $43 \%$ of citizen-informants knew of these MPA's, but few were aware of specific MPA goals, regulations, and impacts. Multivariate statistical analysis of social surveys demonstrated that collaborative MPA planning and implementation processes varied widely between sites (from low to high levels of collaboration), and this explained a significant portion of informants' perception of MPA legitimacy and success (Hard et al., 2012; Hoelting et al., 2013). Based on surveys conducted near 12 MPAs (4 of which overlap with the 2009 sites in Hard et al., 2012; Hoelting et al., 2013) it appears that public awareness of MPAs remains low, with $52 \%$ of general public respondents (of 904 total "grocery store parking lot" informants) unaware of a nearby MPA despite their proximity to a site.

Amongst those aware of a nearby MPA and surveyed at the shores of an MPA in 2014, the nontribal, general public believes that MPAs have positive environmental impacts. $87 \%$ of these respondents believed that MPAs in Puget Sound have either a positive $(38 \%)$ or very positive (49\%) effect on the marine environment (of 410 informants). A lower percentage (44\% of 149 informants) believed that MPAs will help address the effects of a changing climate. There remains a low level of public involvement in MPA design and implementation. Of those aware of a nearby MPA, only $7 \%$ of respondents (of 193 total) reported that they had the opportunity to share an opinion about the nearby MPA. Similarly, only $4 \%$ of informants (of 426 total) were involved in the establishment process for a reserve-such as submitting comments, attending meetings, serving on a committee, or volunteering. While public involvement is low, $83 \%$ of the non-tribal informants (of 420 total) remain either supportive or highly supportive of the MPAs. In surveys conducted in 2010 (Hoelting et al., 2013) there was no statistically significant difference in MPA support between various non-tribal interest groups (e.g., fisher, SCUBA diver, property owner, scientist, conservation organization employee). In response to this question in 2014: "How supportive of this reserve are you now?" with $1=$ Very unsupportive and 5 = Very supportive, recreational fishers were slightly less supportive than other stakeholder groups (Mann-Whitney $U$ Test, $N=435, p=0.03$ ). But the sample size was large $(N=173$ for recreational fishers, $\mathrm{N}=262$ for other informant types), so slight differences of opinion between respondent groups resulted in statistically significant findings $(p<.05)$. And the average recreational fisher's response to this question was " 4.3 " or "supportive". The average response for all other respondent groups was " 4.4 ". This generally pro-MPA perspective amongst the non-tribal informants may be due to the perception that MPAs have positive environmental impacts and because $89 \%$ of informants (of 135 total) believe that the MPA they know is managed either adequately, well, or very well. 


\subsection{Treaty tribes and Puget Sound MPAs}

While support for MPAs is strong among the non-tribal public, there have been few recent MPA designations (besides DNR Aquatic Reserves that do not curtail fishing). Among treaty tribe members, their policy institutions, and their fishers, it appears that there is little support for notake MPAs as currently designed and implemented in Puget Sound amongst treaty tribes and their policy institutions. As co-managers of Puget Sound fisheries, the tribes invest in fishery recovery efforts and strongly prefer fishery management methods that do not impinge on their rights to fish in their Usual and Accustomed fishing areas (Singleton, 2009). The tribes understandably expect to play a leadership role, with non-tribal constituencies, in the design and implementation of fishery management policies to ensure full respect and support for their role as fishery co-managers (Singleton, 2009; Treaty Indian Tribes in Western Washington, 2011). In 2003, the Northwest Indian Fisheries Commission, that represents federally recognized treaty tribes in the region, disseminated a position paper that clearly states that treaty tribes would oppose the abrogation of treaty rights through the declaration of no-take MPAs in their Usual and Accustomed fishing areas (NWIFC, 2003). The position paper also states that tribes could support MPAs, but any support would be dependent on clear scientific justification for MPAs, that they should address serious and widespread ecosystem decline (and not only curtail tribal fishing), and the essential role of tribal co-management in design and implementation of any MPA.

"We will work with the appropriate state and federal agencies to maintain a leadership role in the evaluation and application of MPAs as management tools. To the extent these actions are necessary to address a resource problem, the Tribes must be involved in the decisions and will be responsible for regulating activities by tribal members. In the end, these management actions must acknowledge treaty rights and accommodate the traditional relation that the Tribes have with the marine resources ... Because any proposed action that restricts harvest or access would be a diminishment of the tribes' treaty rights, a proposed MPA must be evaluated in the context of all other regulatory alternatives that might achieve the same conservation principle without diminishing any Tribe's treaty rights."'" (NWIFC, 2003:2-3).

Singleton's (2009) analysis, based on a historic review of tribal-Washington State agency interactions, explains the broad tribal reticence to support an expansive MPA policy agendaespecially one not grounded in a clear co-management framework. Federally-recognized tribes in Puget Sound are co-managers of Puget Sound salmon and shellfish resources, meaning that they have formal rights and responsibilities for setting fishing levels and, increasingly to determine habitat restoration goals and policies. While tribes are likely unwilling to formally relinquish fishing rights anywhere in Puget Sound, 2010 key informant interviews indicated that tribal members voluntarily adhered to MPA no-fishing rules in at least two of seven no-fishing MPAs, Sund Rock and Brackett's Landing, to avoid conflict with recreational SCUBA divers (Hard et al., 2012). In short, the Puget Sound tribes vigilantly protect their fisheries co-management role and recall clearly that Washington natural resource agencies had not always defended tribal fishery rights in the past. The current MPA planning processes are in need of refinement if they are result in new no-take MPAs. 


\subsection{Current status of Puget Sound MPAs}

In conclusion, even with strong non-tribal public support, the enthusiasm to expand MPAs in Puget Sound has waned. No new designations or MPA networks have been designated on in the Northwest Straits Initiative processes. The Puget Sound Partnership Action Agenda (PSP, 2016) no longer contains recommendations for MPAs. There have been no new no-take MPA declarations by WDFW in the last decade. The most recent WDNR aquatic reserve declaration was in 2011, although management plans of existing aquatic reserves have been revised within the last couple years. Notably, WADNR sites do not prohibit fishing. Rather, they focus on the improved management of state-owned sub-tidal lands through enhanced review processes of lease application (by large-scale commercial entities such as mines and private mooring buoy owners), environmental education, citizen science programs and other outreach activities. There may be opportunities for future MPA declarations, but only if tribal rights are respected, planning processes are inclusive and attentive to a broad range of constituencies (especially tribal co-managers), and designed to address compelling habitat recovery goals. These lessons relate to large scale restoration.

While the tribes have been generally resistance to MPA declarations, especially no-take MPAs that would impact their treaty-protected and area-specific fishing rights, they have provided leadership in Puget Sound recovery efforts that use different tools. They have advocated for habitat recovery through large-scale restoration projects, fisheries closures for overfished salmon stocks, and shoreline armoring removal that impairs natural sediment deposition (NWIFC, 2016a; b; Treaty Indian Tribes in Western Washington, 2011). This tribally-led 'pivot' away from MPAs documented by our research logically led us to consider what policies and Puget Sound recovery methods the tribes advocated for. This inductive to deductive research approach (Corbin and Strauss, 2015) clearly documented the central and growing influence of the treaty tribes. As our focus shifted, the methods of this study also pivoted from survey methods to qualitative social research employing semi-structured interviews. As stated earlier, qualitative research methods are more commonly used when exploring new topics and more acceptable for tribal informants.

\section{Results: Large scale restoration approach}

\subsection{Embracing multi-benefit restoration planning}

As dwindling salmon populations spurred efforts to recover degraded coastal habitats restoration efforts have expanded. Estuary degradation is recognized as a central driver in salmon population declines in Puget Sound (Montgomery, 2003; Treaty Indian Tribes in Western Washington, 2011). Puget Sound estuary restoration efforts are evolving to deal with accelerating environmental change and increasing social conflicts, notably over conversion of diked farmlands back to coastal wetland habitats. The emphasis on agriculture is no coincidence. Cereghino (2015) reports that Puget Sound's greatest potential for large-scale estuary restoration today is concentrated in three river deltas facing Whidbey Basin: the Snohomish, Stillaguamish, and Skagit. He notes that these estuaries comprise about $60 \%$ of Puget Sound's historic delta tidelands, and unlike the urbanized deltas of the Duwamish and Puyallup, they are not yet permanently impaired by industrial and urban hardscapes. 
The farm community's spirited defense of its land-base in Puget Sound has spurred restoration and conservation leaders to convene contending interests into collaborative planning bodies over the past decade. Snohomish County's Sustainable Lands Strategy (SLS) and the statewide Floodplains by Design (FbD) program are prominent examples of this "multi-benefit" approach to restoration. Interview sources, workshop participants, and public records indicate that this shift in approach reflects the need for reciprocity and social license to secure land, funding, and approvals for restoration projects.

Salmon recovery remains a major driver (and funding source) for estuary restoration in Puget Sound. But successful restoration efforts frequently are designed to deliver broader benefits that arise from tradeoffs and negotiations between farmers, agencies, tribes, and other interested stakeholders and resource users. Collaborative forums such as SLS and FbD enable these negotiations to reach beyond the scale of individual projects, pursuing reciprocal benefits for the broader farm community (Interview, SLS Facilitator and Farmer, 2016) and for habitat. Widening the "solution set" for restoration in this way facilitates pursuit of more diverse social and ecological goals. It also contributes to the breadth of reported benefits from restoration projects in Washington today: mitigating climate-related risks, flood damage, and drainage problems; increasing recreational access to rivers and wetlands; permanently protecting dedicated farmlands; strengthening local economies; protecting clean water; and improving local quality of life (Carey, 2016; Lombard, 2006; NWIFC, 2016a; b).

Estuary restoration in Puget Sound has proved to be slow work, confronting multiple social and institutional hurdles. An estimated 1129 ha (2791 acres) have been re-opened to tides since 2006, slightly more than one third of the target for 2020 set by the Puget Sound Partnership: 2987 ha (7380 acres). Still, estuary restoration is proceeding, even if progress lags regional targets.

The Snohomish River estuary is an exception. Restoration projects are approaching the 10-year target of 501 ha (1237 acres) to support salmon recovery (Snohomish County, 2005; NWIFC, 2016a; b), and planners are contemplated expanding their goals, in part to address climate impacts. In this estuary, modeling studies suggest that sea level rise (SLR) could dramatically expand saltmarsh and transitional marsh, while degrading other habitats (Glick et al., 2007). Saltmarsh is a high-value habitat for Endangered Species Act-listed chinook salmon, providing prized feeding grounds for juveniles (Beamer et al., 2016). Moderate scenarios for 21st century SLR (0.27 m-0.69 m increase) may expand saltmarsh area by at least an order of magnitude in the Snohomish delta, a pattern also expected in some other regional estuaries (Glick et al., 2007; Sandell and McAninch, 2013). Meanwhile, flooding, saltwater intrusion, drainage problems, and dike failures are impacting delta soils (Grossman, 2016), rendering once fertile lands unproductive (Snohomish County, 2010). Conceding the inevitable, some Snohomish County farm leaders have begun negotiating for "land swaps" and other accommodations with the restoration community (Snohomish County, 2010; Snohomish County Agricultural Advisory Board, 2014). 
Population growth and development are also amplifying pressure on farms and salmon habitat in Snohomish County; rapid population growth has concentrated heavily in floodplains (Alberti et al., 2013). The spread of impermeable surfaces is outpacing restoration efforts. In the county's urban areas $>40 \%$ of surface area has been paved or otherwise hardened, and degraded conditions (> 12\% impervious) have spread into rural zones (NWIFC, 2016a; b).

Confronting these forces, restoration practitioners report that multi-benefit planning is aiding their progress. However, they wonder if this progress is rapid enough. To explore this quandary, we examined the practice of multiple-benefit planning to address environmental and social pressures at Qwuloolt, a large-scale restoration project.

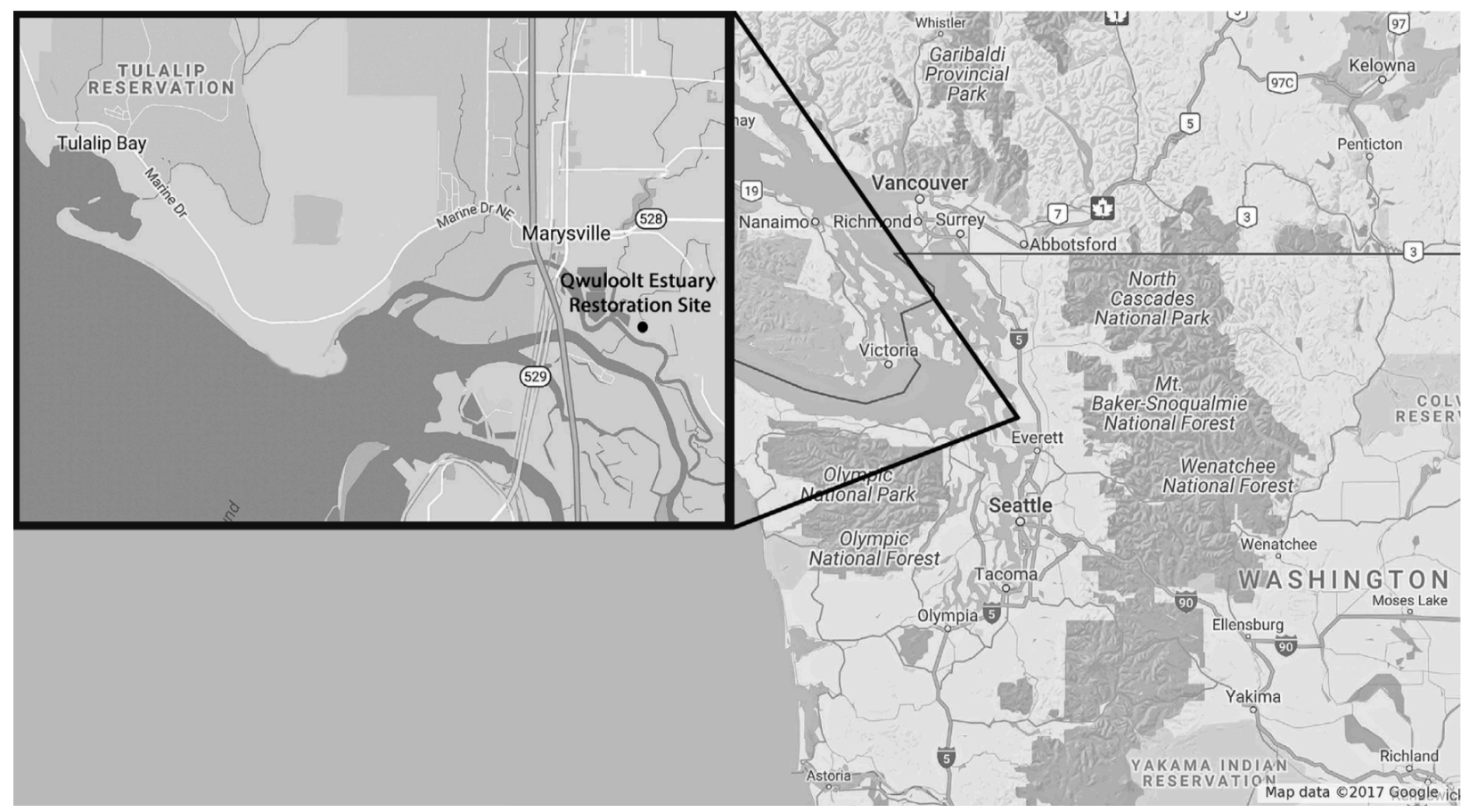

Fig. 2. Puget sound, Tulalip reservation and qwuloolt estuary restoration site.

\subsection{Qwuloolt: restoration in a complex, urbanizing landscape}

Much of our research focused on the Qwuloolt Estuary Restoration Project, a restoration project led by the Tulalip Tribes and the Natural Resource Trustees near Marysville and the Tulalip Reservation (Fig. 2). Qwuloolt began as a mitigation project to offset the environmental damage done by the Tulalip Landfill (designated as a Superfund site after Tulalip litigated to halt illegal dumping of toxic materials by nontribal entities) (Table 2). Qwuloolt is a large (162 ha, 400 acres) tidal estuary restoration project located within the growing urban area of the City of Marysville (http://www.qwuloolt.org/). The key ecological role of the estuary is clearly identified and restoration goals focus largely on benefits to salmon, habitat, and restoration of ecosystem processes. With tribal leadership and collaborative involvement by multiple stakeholders - federal agencies to farmers - the project is typical of today's major estuary restoration efforts in Puget Sound. While Qwuloolt is celebrated as a success in many ways, the project's complexity led to unforeseen costs and delays. It took 20 years and \$20.5 million to 
reach the point of breaching the dike in 2015. That celebrated event followed years of difficult negotiations between multiple partners, donors, permitting agencies, property owners, and jurisdictions. Restoration practitioners interviewed for this study saluted the project's achievements but resolutely hoped that future projects could thread these challenges more simply and quickly.

Table 2. Qwuloolt timeline.

\begin{tabular}{|c|c|}
\hline Settlement - 1938 & $\begin{array}{l}\text { - Estuary completely cleared of original forest } \\
\text { - Converted to farmland through series of } \\
\text { levees }\end{array}$ \\
\hline 1983-1964 & - Agricultural development continues \\
\hline 1964-1979 & $\begin{array}{l}\text { - Seattle Disposal Company Landfill in operation } \\
\text { - Accumulates four million tons commercial and } \\
\text { industrial waste } \\
\text { - Landfill fills in } 147 \text { acres of estuary } \\
\text { - Waste improperly stored, leaches toxins into } \\
\text { estuary }\end{array}$ \\
\hline 1994 & $\begin{array}{l}\text { - Natural Resource Trustee Council formed to } \\
\text { assess damages from landfill site and generate } \\
\text { restoration options }\end{array}$ \\
\hline 1995 & $\begin{array}{l}\text { - Tulalip Landfill designated a Superfund Site by } \\
\text { EPA }\end{array}$ \\
\hline 1997 & $\begin{array}{l}\text { Qwuloolt project selected as best option for } \\
\text { recovering lost wetlands and mitigating landfill } \\
\text { damage }\end{array}$ \\
\hline 1994-2006 & - Qwuloolt Project scoping \\
\hline $2008-2012$ & - Design and permitting \\
\hline 1994-2015 & - Property acquisitions and easements secured \\
\hline $2008-2015$ & $\begin{array}{l}\text { Phase 1: Structural elements including: stream } \\
\text { restoration, topographic restoration, native } \\
\text { vegetation planting, structure demolition, } \\
\text { garbage removal }\end{array}$ \\
\hline $2013-2015$ & $\begin{array}{l}\text { - Phase 2: Process elements including: setback } \\
\text { levee construction (Western edge levee) and } \\
\text { levee breaching (Southern edge levee) }\end{array}$ \\
\hline 2015 & - Southern levee breached \\
\hline 2015-present & - Ongoing collaborative monitoring \\
\hline
\end{tabular}

\subsection{Objectives of large-scale estuary restoration}

As discussed previously, restoration projects in Puget Sound have a range of objectives, principally restoration of habitat and ecosystem processes (Stinchfield et al., 2008), salmon recovery (Shared Strategy Development Committee, 2007), and flood control (Arkema et al., 2013; Wagner, 2014; Wrona Meadows et al., 2012). The focus on salmon habitat restoration, at Qwuloolt was clear in our interviews: "It's very pragmatic to restore habitat, right? ... If you don't have habitat, you don't have much of anything." (Tulalip Staff Interview 2016). Healthy 
habitat was also described as underpinning the value of tribal treaty rights. "Habitat is a big, big part of treaty rights in my view and from the work that I see done in natural resources" (Tulalip Staff Interview 2016). Tribal and non-tribal interviewees both emphasized the importance of salmon from an ecological, economic, and cultural perspective, and a desire to preserve them for future generations: "We're not gonna rebuild the salmon runs with just one Qwuloolt, but maybe we save enough to where my grandchildren of great-grandchildren are able to harvest some salmon. You know that's the main objective is protecting it for the future generations" (Tulalip Staff Interview 2016). More broadly, protecting and restoring culturally significant resources is also a goal: "The mission or the goal of what we're doing here is restoring, protecting natural resources in perpetuity for the Tulalip culture, as well as just all the different plants and animals and water and air resources that the Tribe depends on." (Tulalip Staff Interview 2016).

\subsection{The need for multiple-benefit approach in an urban restoration project}

The institutional structures of large scale restoration projects in Puget Sound reflect a complex and multi-stakeholder environment. This complexity sometimes acts as a barrier to restoration, making collaborative efforts increasingly important (Stinchfield et al., 2008). The "multiple benefit" approach to restoration projects in Puget Sound has shaped process, objectives, and outcomes, even though Qwuloolt was not an official SLS or FbD project. Earlier large-scale estuary restoration projects have mostly occurred on lands controlled by resource management agencies, but Qwuloolt faced particular challenges: the site lay within the boundaries of the City of Marysville and it was originally controlled by multiple landowners, some of whom were actively farming. This increased the complexity, number of stakeholders, and need of a multiple-benefit approach. Through years of negotiating, relationship-building, and identification of creative solutions, the majority of landowners agreed to sell largely inundated lands. The recognition that landowners were key to the success of this project was evident: "Every one of them were important pieces of the puzzle we were trying to put together. Because in order to restore this and flood people's property, we needed 100\% buy-in" (Snohomish County Staff Interview 2016). Partnerships with the City of Marysville were also described as collaborative and respectful working relationships, particularly at a high level (i.e., between the Tulalip Board and the Mayor of Marysville), which were viewed as key to the success of the project.

\subsection{The importance of trust-building and process in large Scale Restoration}

Multi-benefit projects have ultimately been successful in garnering support of key stakeholders through a slow but deliberate process of trust and relationship building. Multiple individuals interviewed for this study emphasized the crucial role of building personal trust and understanding among key players on the landscape in order to build capacity for collaborative planning. "When the SLS started, the first year was just about getting to know each other, it wasn't even about projects, it was about building the trust between tribal entities, the farm community, the restoration community, and just getting to know each other" (Farmer and SLS Member Interview 2016). In Qwuloolt specifically, Tulalip made an effort to bring people involved in the project together to build trust, get to know one another, and celebrate their 
successes. One event in particular, a shared meal of traditional foods, drew project staff "from all over the Sound, all of these people. It connected for them why the tribes were doing this. And I think if there was anything that may have pushed forward some institutional relationship attitudes, it was instances like that" (Tulalip Staff Interview 2016).

\subsection{Tribal leadership and commitment in large Scale Restoration projects}

While numerous state and federal agencies are engaged in restoration, the importance of tribal, non-profit, and county-level leadership is becoming increasingly apparent (Warren, 2015). Our interviewees consistently reported that tribal leadership is both indispensable and growing in restoration work: "the Tribes are absolutely critical players at the table. And for us to try to do much without Tribal support would be a fool's errand." (SLS Member Interview 2016). One interviewee stated that, by his estimation, every recent major restoration project in the region has a tribe in its central leadership (NOAA Staff Interview 2016). Interviews with tribal staff about Qwuloolt emphasized that tribal involvement in restoration is a result of deeply rooted cultural and livelihood ties to the fish resources these ecosystems support: "We are a fishing people [...] you can't place an economic value on that, because that is a living culture we are sustaining" (Tulalip Staff Interview 2016). As a result of these ties, Tulalip and other tribes in the region see themselves as default leaders of this work, and their neighbors sometimes share that view.

\subsection{A need to speed the pace of long-timeline projects}

The ecological effects of restoration work take years to be realized. While interviewees recognized the immediate physical and visual changes that occur in restoration projects, they are cognizant that the long timelines of these projects must be shortened and the pace of restoration increased. For example, many of our interviewees were present at the "breach ceremony" - the completion - of the Qwuloolt project: "seeing that habitat back into production hoping that's going to help offset some of these problems we have in the river but knowing that it's just a small, really a small, drop in the bucket" (Tulalip Staff Interview 2016). The costs and delays incurred in this complex project worry practitioners seeking to speed the pace of restoration. When asked if Qwuloolt represents a model for the future restoration efforts, one interviewee responded: "It can't be. If we're going to reach our target restoration goals to restore the health of Puget Sound in an efficient manner, that's going to break everybody. It's not going to work" (WDFW Interview 2016). Yet several interviewees noted that the challenged faced at Qwuloolt are likely to become more common as coastal estuary degradation continues, pushing restoration managers to thread an increasingly complex maze of competing interests on the landscape.

\section{Discussion}

Establishing MPAs or restoring estuaries changes how people can use coastal spaces where they live, work or recreate. In Puget Sound, this simple fact means that securing social license amounts to a threshold, a "make-or-break" challenge for these conservation and recovery measures. Our research lends support to the view that this threshold may be where the two management aproaches have diverged in Puget Sound. Designation of new MPAs has mostly 
ground to a halt, while new estuary restoration projects are underway. We identified differences in planning approach that may help to account for this fork in the road.

We consider four factors that practitioners and relevant studies described as influential in achieving restoration and conservation designations: 1 ) engaging affected publics; 2) building trust and relationships with them; 3) harnessing those interactions to shape projects that can deliver multiple social and ecological benefits (thus delivering some reciprocity for affected groups); and 4) the influence of tribal leadership.

We found that public involvement in MPA design and implementation has been low: only $4 \%$ of survey informants queried about MPAs said they had commented, attended meetings, volunteered or participated in decisions and planning to establish a protected area. Although we lack comparable quantitative data for restoration projects, we documented extensive citizen participation in restoration planning initiatives through public records, accounts of interview subjects, and gray literature. Snohomish County farmers participate in monthly meetings of the SLS Executive Committee, which a farmer co-chairs; they engage vigorously in restoration planning decisions through the county's Agricultural Advisory Board, which also meets monthly; they also speak out in other public forums (Snohomish County, 2014). Cereghino (2015) and practitioners interviewed for this research reported that relationships and trust built through such participation-and through personal contacts outside of meetings - are key factors in the success of restoration projects.

Informants in our restoration interviews noted repeatedly that building local support and trust requires a sustained investment in relationship building. They described this work as crucial, time consuming, and extremely difficult to fund. It takes a lot of conversation and iteration to understand concerns of affected people and frame projects to deliver multiple benefits that they value.

Interviewees and workshop participants noted that tribal leadership has brought important strengths to Puget Sound estuary restoration. The tribes' resource management expertise, leadership capacity, and commitment to their home river basins and salmon culture were repeatedly described as vital drivers of the Qwuloolt project and the wider regional commitment to protect and restore Puget Sound. "Thank you to the leadership of Tulalip, for enabling (staff) to innovate and lead in and outside the tribe ... They are part of a long-term success." (Stelle, 2016).

So far, proponents of MPAs in Puget Sound have had less success in finding comparable means to enfranchise tribes affected by these protection measures. Tribes have questioned efficacy and applicability of MPAs to the broad challenges facing Puget Sound recovery, and have noted their intention to preserve culturally important fisheries as healthy fish stocks through their own authorities. Most importantly, and related to our research on the human dimensions of both MPAs and restoration projects, tribes have not been effectively engaged as comanagers in visioning and designing MPAs. They have, as a result of how MPAs goals and planning processes have been created and mainly led by federal and state government agencies, firmly and 
justifiably expressed their legal right as co-managers. The MPA planning process has been paused, but it is also possible that MPA planning can take a new and improved direction. Based on this research, 'restarting' MPA planning based on collaborative planning tenets, trust building, and other key MPA best practices would be essential to progress (Hard et al., 2012; Hoelting et al., 2013, Pollnac et al., 2010). The ESA-listed rockfish recovery plans have identified MPAs as a preferred management option.

As practitioners and resource managers consider how to cope with intensifying environmental pressures in Puget Sound, they see human and institutional challenges looming larger in the future (Tulalip, NOAA, WDFW, Snohomish County interviews 2016). Rising waters and population growth are compressing the basin's remaining estuarine bottomlands (Alberti et al., 2013). Farms, roads, businesses, and hundreds of thousands of new residents are contending for space against an increasingly unruly ocean and rivers (Alberti et al., 2013; NWIFC, 2016a; b). On this changing coast, multi-benefit planning may offer a path toward greater social and ecological resilience. However, navigating this path will demand high (possibly unprecedented) levels of collaboration, leadership, adaptive learning and investment.

\section{Conclusions}

1. In developing protected areas for marine fish and habitat recovery, some MPA proponents and agencies have not yet demonstrated a sound understanding of resource user rights and governance systems or the application of such information to shape planning processes. Currently, MPA planning processes are drawing from limited understanding of how institutions can effectively collaborate and how complex social groups perceive MPAs and can be brought together to shape and support MPAs.

2. While non-tribal public support exists for MPAs in Puget Sound, the collaborative planning process employed to develop these protective measures has been weak. Especially lacking is recognition of co-management with treaty tribes, a key social group, in design, implementation, enforcement, and monitoring of protected areas, as tribes themselves have noted (NWIFC, 2003; Moon, 2005). As in estuary restoration, collaborative and broadly inclusive planning is essential to MPA implementation. Tulalip Tribes and partners demonstrated sound practice in planning for Qwuloolt restoration by engaging resistant landowners collaboratively and addressing their concerns.

3. The co-management role of treaty tribes is an important policy condition that shapes Puget Sound recovery efforts. Tribal leadership is evident in fisheries recovery and restoration projects. Recognizing the tribes' leadership role opens many opportunities for multi-institutional initiatives and funding streams. Conversely, failure to recognize their leadership role has contributed to a stalemate in MPA planning, in which potentially workable solutions are left unexplored.

4. Tribal resistance to MPA designation (NWIFC, 2003) has underscored concerns that protected areas could impinge upon tribal harvest rights while doing little to address recognized problems in Puget Sound. But where tribes see conservation measures as necessary and effective, they commonly accept, advocate, and selfimpose restrictions on harvests; they also supported ESA listings to protect Puget Sound chinook salmon and Hood Canal summer chum salmon (NWIFC, 2016a; b). 
5. Estuary restoration practitioners, policymakers, and funders recognize a need to accelerate progress and show keen interest in learning approaches to do it. Participants in the Navigating Coastal Squeeze Workshop in December 2016 offered multiple suggestions for potential improvements in practice, experiments to assess possible efficiencies, and options for sharing human resources, pooling funds, and advancing learning. As a community, they welcome suggestions from other practitioners and scholars and show interest in developing a "learning network" as a way to increase capacity to achieve restoration goals. Such learning networks are means toward leadership creation, lesson sharing, and innovation (Christie et al., 2016).

\section{Recommendations}

The following recommendations are not comprehensive, but are timely and achievable based on this research and assessment of future needs for Puget Sound recovery and in agreement with adaptive restoration practice (Zedler, 2017).

\subsection{Study the nature of the resource being protected or managed; study users and rights to understand roles, resource use overlaps, conflicts and complementarity}

Clear rights and responsibilities are the basis for effective governance. In Puget Sound, a historically-grounded understanding of the interaction between tribal, state, and federal jurisdictions is essential before policy development.

\subsection{Study how people do collaborative planning and apply lessons to restoration and} protection efforts in Puget Sound

Initiatives to foster multi-benefit restoration around Puget Sound offer living laboratories for human dimensions research to help speed restoration planning. Well-designed research could inform these efforts, by identifying successful and replicable models for accelerating the process in order to aid practitioners. Human dimensions/governance assessments, for example, are commonly used to support collaborative planning efforts and could help to advance restoration and conservation processes. Guidance for such assessments is readily available (Bennett et al., 2017; https://www.st.nmfs.noaa.gov/humandimensions/index).

\subsection{Invest in basin-scale initiatives to foster trust, relationships and capacity for building common ground and multi-benefit restoration plans \\ Lack of resources for the patient work of securing social license or approval of local land- owners, tribes, and other social key groups is a widely recognized impediment to restoration and conservation projects. Forums that facilitate this work play an indispensable role in enabling progress.}

\subsection{Convene a regional learning network of restoration practitioners and policymakers} Capturing and disseminating lessons learned directly from the people doing restoration work could speed adaptive management on a changing coast. A learning network might help the 
region learn to better muster its strengths to build agile and successful collaborations in spatial conservation and management.

\subsection{Develop predictive decision-support tools}

Improved prediction capabilities are necessary to guide restoration investments and site selection, in order to ensure that projects can deliver intended benefits in a changing environment as flooding, sea level rise and human activities alter the functions of habitats.

\section{Acknowledgements}

The authors would like to thank all those interviewed for this project for sharing their time and expertise with us. We would also like to specifically thank our partners in organizing the workshop in December of 2016, Morgan Ruff, Josh Meidav, and Preston Hardison of the Tulalip Tribes, Abby Hook of Hook Environmental, and Dani Ziff of SMEA. This research was generously supported with Washington Sea Grant funding (through NOAA Award NA14OAR4170078 and Puget Sound Partnership Agreement \#2014-12 AM02). The "Navigating Coastal Squeeze" 2016 workshop was organized jointly by this research team and Tulalip Tribes, with funding from Washington Sea Grant, Tulalip Tribes, and the US Bureau of Indian Affairs.

\section{References}

Alberti, M., Russo, M., Tenneson, K., 2013. Snohomish Basin 2060 Scenarios. Urban Ecology Research Lab, University of Washington.

Arkema, K., Guannel, G., Verutes, G., Wood, S., Guerry, A., Ruckelshaus, M., Kareiva, P., Lacayo, M., Silver, J., 2013. Coastal habitats shield people and property from sealevel rise and storms. Nat. Clim. Change 3, 913-918.

Beamer, E., Brown, B., Wolf, K., Henderson, R., Ruff, C., 2016. Juvenile Chinook Salmon and Nearshore Fish Use in Habitat Associated with Crescent Harbor Salt Marsh, 2011 through 2015. Skagit River System Cooperative Research Program Prepared for US Department of the Navy. Whidbey Island Naval Air Station.

Bennett, N., Roth, R., Klain, S., Chan, K., Christie, P., Clark, D., Cullman, G., Curran, D., Durbin, T., Epstein, G., Greenberg, A., Nelson, P., Sandlos, J., Stedman, R., Teel, T., Thomas, R., Verissimo, D., Wyborn, C., 2017. Conservation social science: understanding and integrating human dimensions to improve conservation. Biol. Conserv. 205, 93-108.

Bish, R., 1982. Governing Puget Sound. Washington Sea Grant Publication, University of Washington Press, Seattle, pp. 137.

Bish, R., Warren, R., Weschler, L.F., Crutchfield, J., Harrison, P., 1975. Coastal Resource Use: Decisions on Puget Sound. Washington Sea Grant Publication, University of Washington Press, Seattle, pp. 206. 
Burns, R., 1990. The Shape and Form of Puget Sound, second ed. Washington Sea Grant Publication, University of Washington, pp. 100.

Carey, B., 2016. A River Revolution: from 0 to 56 in Four Years. Floodplains by Design. http://www.washingtonnature.org/fieldnotes/2016/7/14/a-river-revolution-from0-to-56-infour-years Accessed 4/February0/2018.

Cereghino, P., 2015. Recommendations for accelerating estuary restoration in Puget sound. In: Prepared for the Puget Sound Partnership and Washington Department of Fish and Wildlife by NOAA Fisheries Restoration Center, Seattle, WA, pp. 20.

Chasan, D., 1981. The Water Link: a History of Puget Sound as a Resource. Washington Sea Grant Publication. University of Washington Press, Seattle, pp. 179.

Christie, P., Pietri, D.M., Stevenson, T.C., Pollnac, R., Knight, M., White, A.T., 2016. Improving human and environmental conditions through the coral triangle initiative: progress and challenges. Current Opinion in Environmental Sustainability (COSUST) 19, 169-181.

Corbin, J.M., Strauss, A.L., 2015. Basics of Qualitative Research: Techniques and Procedures for Developing Grounded Theory. Sage, Los Angeles.

Dudley, N. (Ed.), 2008. Guidelines for Applying Protected Area Management Categories. Gland, Switzerland. IUCN, pp. 86.

Elliott, M., Burdon, D., Hemingway, K.L., Apitz, S.E., 2007. Estuarine, coastal and marine ecosystem restoration: confusing management and science-a revision of concepts. Estuar. Coast. Shelf Sci. 74, 349-366.

Gelfenbaum, G., Mumford, T., Brennan, J., Case, H., Dethier, M., Fresh, K., Goetz, F., Van Heeswijk, M., Leschine, T.M., Logsdon, M., Myers, D., Newton, J., Shipman, H., Simenstad, C.A., Tanner, C., Woodson, D., 2006. Coastal Habitats in Puget Sound: a Research Plan in Support of the Puget Sound Nearshore Partnership. Puget Sound Nearshore Partnership, Seattle, WA, pp. 50 Technical Report 2006-1.

Given, L.M., 2008. The SAGE Encyclopedia of Qualitative Research Methods. SAGE Publications Ltd, Thousand Oaks, CA. http://dx.doi.org/10.4135/9781412963909.

Glick, P., Clough, J., Nunley, B., 2007. Sea-level Rise and Coastal Habitats in the Pacific Northwest: an Analysis or Puget Sound, Southwestern Washington, and Northwestern Oregon. National Wildlife Federation.

Grossman, E., 2016. Personal communication. In: Presentation at Navigating Coastal Squeeze Workshop, Tulalip, WA, December 12, 2016, (derived from article in preparation). 
Gunderson, D., Parma, A., Hilborn, R., Cope, J., Fluharty, D., Miller, M., Vetter, R., Heppell, S., Greene, H., 2008. The challenge of managing nearshore rocky reef resources. Fisheries 33, 172179.

Hard, C., Hoelting, K., Christie, P., Pollnac, R., 2012. Collaboration, legitimacy and public awareness: a case study of Puget Sound MPAs. Coast. Manag. 40, 312-326.

Hoelting, K.H., Hard, C.H., Christie, P., Pollnac, R.B., 2013. Factors affecting support for Puget Sound marine protected areas. Fish. Res. 144, 48-59.

Kirlin, J., Caldwell, M., Gleason, M., Weber, M., Ugoretz, J., Fox, E., Miller-Henson, M., 2013. California's Marine Life Protection Act Initiative: supporting implementation of legislation establishing a statewide network of marine protected areas. Ocean Coast Manag. 7, 3-13.

Lombard, J., 2006. Saving Puget Sound: a Conservation Strategy for the 21st Century. American Fisheries Society, Bethesda, MD, pp. 336 in association with the University of Washington Press. Seattle.

Miles, M.B., Huberman, A.M., 1994. Qualitative Data Analysis, second ed. Sage Publications, Newbury Park.

Montgomery, D.R., 2003. King of Fish the Thousand-year Run of Salmon. Westview Press, Boulder.

Moon, M., 2005. Tribal and Local Input Must Go into Creation of Marine Protected Areas, NWIFC Blog, Aug 19,2005. Northwest Indian Fisheries Commission.

Murray Metcalf Commission, 1998. Report to the Convenors. Northwest Straits Commission, Mt. Vernon, WA, pp. 12 August 20.

Murray, M., Ferguson, L., 1998. The status of marine protected areas. In: Proceedings of the Puget Sound Research Conference, Seattle, WA. Puget Sound Water Quality Action Team, Seattle, WA, pp. 783-793.

National Marine Fisheries Service (NMFS), 2016. Draft Rockfish Recovery Plan: Puget Sound/Georgia Basin Yelloweye Rockfish (Sebastes Ruberrimus) and Bocaccio (Sebastes Paucispinis). National Marine Fisheries Service, Seattle, WA, pp. 80.

Northwest Indian Fisheries Commission (NWIFC), 2003. Tribal Policy Statement on Marine Protected Areas, Marine Reserves, Marine Sanctuaries, and Fishery Conservation Zones. pp. 3 Olympia, WA. 
NWIFC, 2016a. State of Our Watersheds: a Report by the Treaty Tribes in Western Washington. Northwest Indian Fisheries Commission, Olympia, WA.

https://geo.nwifc.org/SOW/SOW2016 Report/SOW2016.pdf, Accessed date: 20 April 2018.

NWIFC, 2016b. Climate Change and Our Natural Resources: a Report from the Treaty Tribes in Western Washington. Northwest Indian Fisheries Commission, Olympia WA. http://nwifc.org/w/wp-content/uploads/downloads/2017/01/CC and Our NR Report 20161.pdf, Accessed date: 20 April 2018.

Osterberg, A., 2012. Developing a Network of Marine Protected Areas in Puget Sound. A Synthesis Report on Challenges, Opportunities and Policy Options. A report prepared for the Puget Sound Partnership under WA Sea Grant Hershman Fellowship program. Puget Sound Partnership, Seattle, WA, pp. 79.

Pollnac, R., Christie, P., Cinner, J.E., Dalton, T., Daw, T.M., Forrester, G.E., Graham, N.A.J., McClanahan, T.R., 2010. Marine reserves as linked social-ecological systems. In: Proceedings of the National Academy of Sciences of the United States of America (PNAS), vol. 107. pp. 1826218265.

Puget Sound Partnership (PSP), 2012. The 2012/2013 Action Agenda for Puget Sound. http://www.psp.wa.gov/downloads/AA2011/083012_final/Action\%20Agenda\%20Book\%202_A ug\%2029\%202012.pdf, Accessed date: 20 April 2018.

PSP, 2016. The 2016 Action Agenda for Puget Sound Comprehensive Plan. http://www.psp.wa.gov/action-agenda-document.php, Accessed date: 20 April 2018.

Ruckelshaus, M., Essington, T., Levin, P., 2009. Puget sound, Washington, chapter 12. In: McLeod, K., Leslie, H. (Eds.), Ecosystem-based Management for the Oceans. Island Press, Covelo, pp. 201-226 pp. 338.

Saldaña, J., 2010. The Coding Manual for Qualitative Researchers. Sage Publications, Los Angeles.

Sandell, T., McAninch, A., 2013. Climate Change in the Chehalis River and Grays Harbor Estuary. Wild Fish Conservancy. Report prepared for the Chehalis Basin Habitat Work Group.

Shared Strategy Development Committee, 2007. Puget sound salmon recovery plan.Adopted by the National Marine Fisheries Service January 19.

http://www.westcoast.fisheries.noaa.gov/publications/recovery planning/salmon steelhead/d omains/puget sound/chinook/pugetsoundchinookrecoveryplan.pdf.

Simenstad, C., Ramirez, M., Burke, J., Logsdon, M., Shipman, H., Tanner, C., Toft, J., Craig, B., Davis, C., Fung, J., Bloch, P., Fresh, K., Myers, D., Iverson, E., Bailey, A., Schlenger, P., Kiblinger, C., Myre, P., Gerstel, W., MacLennan, A., 2011. Historical Change of Puget Sound Shorelines: 
Puget Sound Nearshore Ecosystem Project Change Analysis. Published by Washington Department of Fish and Wildlife, Olympia, Washington, and U.S. Army Corps of Engineers, Seattle, Washington, pp. 289 Puget Sound Nearshore Report No. 2011-01.

Singleton, S., 2009. Native people and planning for marine protected areas: how "stakeholder" processes fail to address conflicts in complex, real-world environments. Coast. Manag. 37, 421440.

Smith, L.T., 2012. Decolonizing Methodologies: Research and Indigenous Peoples, second ed. Zed Books and Dunedin, N.Z.: University of Otago Press, London.

Snohomish County Agricultural Advisory Board, 2014. Audio recording of meeting, June 10, 2014. http://snohomish.granicus.com/ViewPublisher.php?view id=9, Accessed date: 20 April 2018.

Snohomish County, 2005. Snohomish River Basin Salmon Conservation Plan, June 2005. Snohomish County Surface Water Management Division, Everett WA. http://snohomishcountywa.gov/ArchiveCenter/ViewFile/Item/2153, Accessed date: 20 April 2018.

Snohomish County, 2010. Snohomish county comments on ebey island draft alternatives and ranking process, aug 10, 2010. In: In Washington Department of Fish and Wildlife Record of Public Comments on Ebey Island Planning, . http://wdfw.wa.gov/lands/wildlife areas/snoqualmie/ebey/comments08102010.pdf, Accessed date: 20 April 2018.

Stinchfield, H.M., Koontz, L., Sexton, N.R., 2008. Social and Economic Considerations for Coastal and Watershed Restoration in the Puget Sound, Washington-A Literature Review. pp. 78 U.S. Geological Survey Open-File Report 2009-1079.

Stelle, W., 2016. National oceanographic and atmospheric administration (NOAA) regional director. pers. comm In: Speaker at Navigating Coastal Squeeze Workshop, December 12.

Treaty Indian Tribes in Western Washington, 2011. Treaty Rights at Risk: Ongoing Habitat Loss, the Decline of the Salmon Resource, and Recommendations for Change.

Tuler, S., Webler, T., Shockey, I., Stern, P., 2002. Factors influencing the participation of local governmental officials in the national estuary program. Coast. Manag. 30, 101-120.

Van Cleve, F., Bargmann, G., Culver, M., the MPA Work Group, 2009. Marine Protected Areas in Washington: Recommendations of the Marine Protected Areas Work Group to the Washington State Legislature. Washington Department of Fish and Wildlife, Olympia, WA, pp. 118. 
Wagner, E., 2014. Nature Inspires a New Approach to Flood Control. Published 11.19.2014 on Encyclopedia of Puget Sound. https://www.eopugetsound.org/magazine/floodplains, Accessed date: 20 April 2018.

Warren, B., 2015. Building common ground: a report on the Snohomish triple value simulation pilot study, 2013-2014. In: Prepared for the Tulalip Tribes of Washington by the National Fisheries Conservation Center, Seattle, WA, pp. 54.

Washington Department of Fish and Wildlife (WDFW), 2011. Final Puget Sound Rockfish Conservation Plan, Policies, Strategies and Actions Including Preferred Range of Actions. WDFW, Olympia, WA, pp. 223.

Williams, T., Hardison, P., 2012. Climate threats to pacific Northwest tribes and the great ecological removal: keeping traditions alive. In: Grossman, Z., Parker, A. (Eds.), Asserting Native Resilience: Pacific Rim Indigenous Nations Face the Climate Crisis. Oregon State University Press, Corvallis, OR, pp. 53-68 239 pp.

Wrona Meadows, A., Brumbaugh, B., Rychwalski, E., Chrisley, K., Carter, J., Hancock, B., 2012. Investing in Nature: Creating Jobs and Restoring Coastal Habitats. The Nature Conservancy, Arlington, VA, pp. 43 Aug 10, 2012.

Zedler, J., 2017. What's new in adaptive management and restoration of coasts and estuaries? Estuar. Coast 40, 1-21. 